\title{
Importance of Soft Skills for Graduates in the Real Estate Programmes in Malaysia
}

\author{
Yasmin Mohd Adnan, Md Nasir Daud, Anuar Alias \\ Faculty of Built Environment \\ University of Malaya \\ Muhammad Najib Razali \\ Faculty of Engineering and Geo Information \\ Universiti Teknologi Malaysia
}

\begin{abstract}
The current employment market in Malaysia requires the graduates to be more workplace competent, hence requiring the necessary soft skills. This paper attempts to highlight the key soft skills that have been identified by the Ministry of Higher Education (MOHE), Malaysia in its move to enhance graduates' employability. To incorporate these soft skills in the undergraduate programmes at universities, MOHE has suggested the following implementation methods to enhance these soft skills for the undergraduate programmes at universities. They are development of soft skills by embedding it in the existing syllabus, the development of soft skills through stand-alone subject, development of soft skills based on campus life, development of soft skills on support programmes, soft skill finishing schools, development of soft skills base on formal and informal activities at faculty levels, and lastly industrial training. Views from the industry are sought to provide an indication of the importance of the identified key soft skills in the real estate area so as to make the necessary emphasis on the curriculum development.
\end{abstract}

Keywords: Undergraduates, employability, soft skills, real estate

\subsection{Introduction}

The real estate profession professional standards in Malaysia are maintained through a combination of appropriate university education, applied experience, standards for admission to professional bodies and continuing professional education. The role that universities offering the undergraduate programmes play is to provide and equip graduates with the necessary skills for them to commence their first professional position in the real estate industry. Institutions such as the Board of Valuers, Appraiser and Estate Agents, Malaysia ('BOVAEA"), Royal Institution of Surveyors Malaysia ("RISM”) and Royal Institution of Chartered Surveyors ("RICS") in Malaysia seek to monitor and maintain the quality of university programs through articulating appropriate professional practices and university course evaluation and accreditation. Although these standards are continuously monitored and examined, there have been concerns on the acquisition and delivery of the knowledge with the current challenges of having to ensure that the graduates are employable. The concerns on the employability within the current job market are linked with the changing landscape in the economic and technological activities. An earlier work by the The Organisation for Economic Cooperation and Development (OECD), 2001 has identified the changes that is required by the increasing globalisation of economic activities demanding for new or additional types of competencies among individuals. These competencies are termed as 'workplace competencies' and it was argued that they are complementary to the academic and technical skills that have traditionally been the focus of education and training policy (Adnan and Aini, 2006). It is also 
observed that ICT has also led to the convergence and integration of technologies in production systems requiring higher level technical skills and multiskilling Taylor, 2006). The rapid changes in the industrial structure among the OECD countries, with consequent rapid shifts in the demand for different types and levels of skills, has increased incentives for individuals to acquire adaptable and 'transferable' workforce skills (Kim, 2002). Another study by Archer and Davison in 2008 found that regardless of the size of the company, 'soft skills' (eg communication skills and team-working) were perceived to have more weight than technical or 'hard skills' (eg a good degree qualification, IT skills). Indeed, Glass et al (2008) found that only a minority of employers in their case studies recruit individuals from universities specifically for the technical skills that they hope graduates will bring to the organisation. Rather, most employers see a degree as a proxy for achieving a certain level of competence that represents the minimum standard they are seeking in a new recruit. Recently, OECD's Skills Strategy project (Organisation for Economic Cooperation and Development, 2011) has looked into the evidence of the particular skills and competencies, beyond literacy and numeracy, which can help workers obtain better labour market outcomes and cope with the fluidity of labour markets. In addressing the concerns of the employers for the lack of soft skills among graduates of higher institutions of learning, the Ministry of Higher Education, Malaysia (MOHE) has identified seven (7) key skills to be incorporated in the curriculum design of undergraduate programmes at public universities in Malaysia. As the real estate programmes are not excluded in the implementation exercise, it would be useful to gather insights of the importance of the identified skills from the stakeholders. Thus, it is the aim of this paper to address the implementation aspect for the improvement of the identified soft skills by identifying the relative importance of these skills among the stakeholders namely employers of real estate graduates in Malaysia.

\subsection{Employability within the current job market}

In identifying and developing the skills that are required by the competitive job market, it would be useful to define employability. Employability has been defined as a set of skills, knowledge and personal attributes that make an individual more likely to secure and be successful in their chosen occupation to the benefits of themselves, the workforce, the community and the economy (Moreland, 2006). Employability skills defined in DEST 2002 as 'skills required not only to gain employment, but also to progress within an enterprise so as to achieve one's potential and contribute successfully to enterprise strategic directions.' Ranjit (2009) quoted Brown, Hesketh and Williams (2004) work which had defined employability as "The relative chances of finding and maintaining different kinds of employment". Thus it can be observed that the definition of employability skills relates to the skills that are not job specific, but are skills which cut horizontally across all industries and vertically across all jobs from entry level to chief executive officer. Non-technical skills are commonly referred to as employability skills and include basic skills such as oral communication, as well as higher order skills such as decision making and affective skills, problem solving, learning skills and strategies, and traits such as interpersonal skills (cooperation, team work), dependability and responsibility, self-discipline and selfmanagement a positive attitude, and ability to work without supervision (Cotton, 2001). Cotton (2001) also found that employers value generic employability skills over specific technical skills express deep concerns regarding this deficiency of graduates lacking the required employability skills. 


\subsection{Scenario of Graduate Employability - Locally and Abroad}

Unemployment among graduates in Malaysia has been reported in the local newspapers highlighting the following factors that have brought about the situation (News Strait Times, 2003; Mingguan Malaysia, 2005; News Strait Times, 2005). These factors include graduates' refusal to accept jobs not in line with their qualifications, preference for jobs in the public sector, unwillingness to be self-reliant and poor command of English. It had stated that most employees require workers to possess qualities such as good attitude, strong work ethics, and the ability to communicate well, a willingness to learn and to contribute new ideas. It has been acknowledged by the general consensus of Malaysian employers that Malaysian graduates lack the 'soft skills' although are well trained in their areas of specialisation. (Nurita, Shaharudin, Ainon, 2004).

According to a report on Employability of Malaysian Graduates presented to the Malaysian Economic Action Council in April 2003, the reasons why less local graduates are employed are because they have less exposure, and are not aggressive or dynamic. They tend to be less vocal and open-minded. In United Kingdom, Higher Education Programmes in UK such as Enterprise in Higher Education and Higher Education for Capability Initiatives which involved 60 universities in 1990s emphasised indirect preparation for work through development of personal transferable skills in the mainstream academic curriculum and the Dearing Report supports these initiatives to increase employability (Universities UK and the HECSU, 2002). As observed by Pillai (2009), the grouses from industry about graduates not being ready for the workplace are not unique to Malaysia (e.g. Hii, 2007; Report of the Industry Dialogue, 2008; Sirat, et al, 2008; - Subra: Graduates Lack Dynamism and Edge, 2009), but is in fact a global phenomenon (see Teichler, 1998; West et.al., 2000).

\subsection{Skills Required by Graduates}

In identifying the skills that are required of the graduates, it would be useful to differentiate the hard and the soft skills expected of them. By an earlier definition, hard skills refer to the skills that are associated with technical aspects of performing a job and usually include the acquisition of knowledge (Page \& Kolb, 1993). It is cognitive in nature and is also associated with cognitive skills (Birkett, 1993). On the other hand, soft skills refer to those skills that place emphasis on personal behaviour and managing relationships between people as well as interpersonal, human, people or behavioural skills.. It is primarily affective or behavioural in nature and associated to EQ (Kemper, 1999; Mc Murchie, 1998). Soft skills are also defined as the "interpersonal, human, people or behavioural skills needed to apply technical skills and knowledge in the workplace" (Weber et al. 2009:356). Furthermore, Weber et al. (2009:359) describe entry-level managers or recruits as possessing soft skills when they demonstrate "the ability ... to communicate with others and to understand others on an emotional level".

Ranjit and Wahab, 2008 surveyed 234 human resource managers and 102 hiring managers from about 100 companies and found that the top ten soft skills sought by Malaysian employers are integrity, willingness to learn, communication skills, initiative, achievement orientation, teamwork skills, interpersonal skills, flexibility, high self-esteem and critical thinking skills (Ranjit \& Wahab, 2008) 
The generic soft skills required by graduates in other countries such as UK which have been summarized by the report entitled 'Enhancing employability, recognising diversity - making links between higher education and the world of work, Universities UK and the HECSU in 2002' highlights the following core attributes comprising willingness to learn and continue learning, interpersonal skills, personal attributes - intellect, problem solving, analytic, critical and reflective ability, communication skills, team building, flexibility, adaptability and risktaking.

In Malaysia, the Ministry of Higher Education (MoHE) has identified seven soft skills that should be possessed by all graduates as indicated in the Module for the Development of Soft Skills for Higher Learning Institution Malaysia, 2006 which include the following skills : critical thinking and problem solving skills; communication skills; lifelong learning and information literacy; team-working skills; professional ethics and morality; entrepreneurship skills; and leadership skills.

Educational institutions worldwide, including the United Kingdom, Canada, USA, Australia, New Zealand, Germany and Singapore are currently placing greater emphasis on enhancing graduate employability by buttressing their soft skills and adopting a more employability-oriented approach to the curriculum. (Yim-Teo, 2004). In a 2008 survey, almost all UK universities agreed or agreed strongly that it is important for all graduates to possess employability skills (CBI, 2009).

In facing the challenges of the competitive job market, additional soft skills are required by university graduates. The traditional key areas of knowledge and skills of a specific study area are no longer emphasized as observed by the studies mentioned earlier.

\subsection{Initiatives for the Improvements of Soft Skills at Higher Learning Institutions in Malaysia}

The primary purpose of higher education is to prepare students for the world of work (Lord Dearing, 1997). There has got to be a process of transformation in the learning and teaching process for graduates to face the major challenges by the university graduates Universities now have got to acknowledge that the soft skills of an individual student have to be developed in the process. Developed frameworks have been developed by many countries, such as the USA (e.g. ABET) and Australia (e.g. Engineers Australia). In particular, the field of engineering has provided guidelines to clearly define, monitor and articulate graduate attributes in their curricula. A study by Commonwealth of Australia in 2007 for instance, has shown that Australian universities have had about a decade of experience working with the concept of graduate attributes providing a framework of generic competencies for university graduates. Many universities have addressed the importance of employability skills of their graduates by creating graduates attributes. In the case of the field of engineering, professional bodies such as the Accreditation Board for Engineering and Technology (ABET) and Engineers Australia (EA) have underlined and placed increasingly emphasis on the development of graduate attributes in tertiary engineering students (ABET, 2008; Jolly, 2001; Engineers Australia, 2008).

In Malaysia, the following implementation methods have been suggested by MOHE to enhance these soft skills for the undergraduate programmes at universities. They are development of soft skills by embedding it in the 
existing syllabus, the development of soft skills through stand-alone subject, development of soft skills based on campus life,development of soft skills on support programmes, soft skill finishing schools, development of soft skills based on formal and informal activities at faculty levels, and lastly industrial training. This can be summarised as in Figure 1:

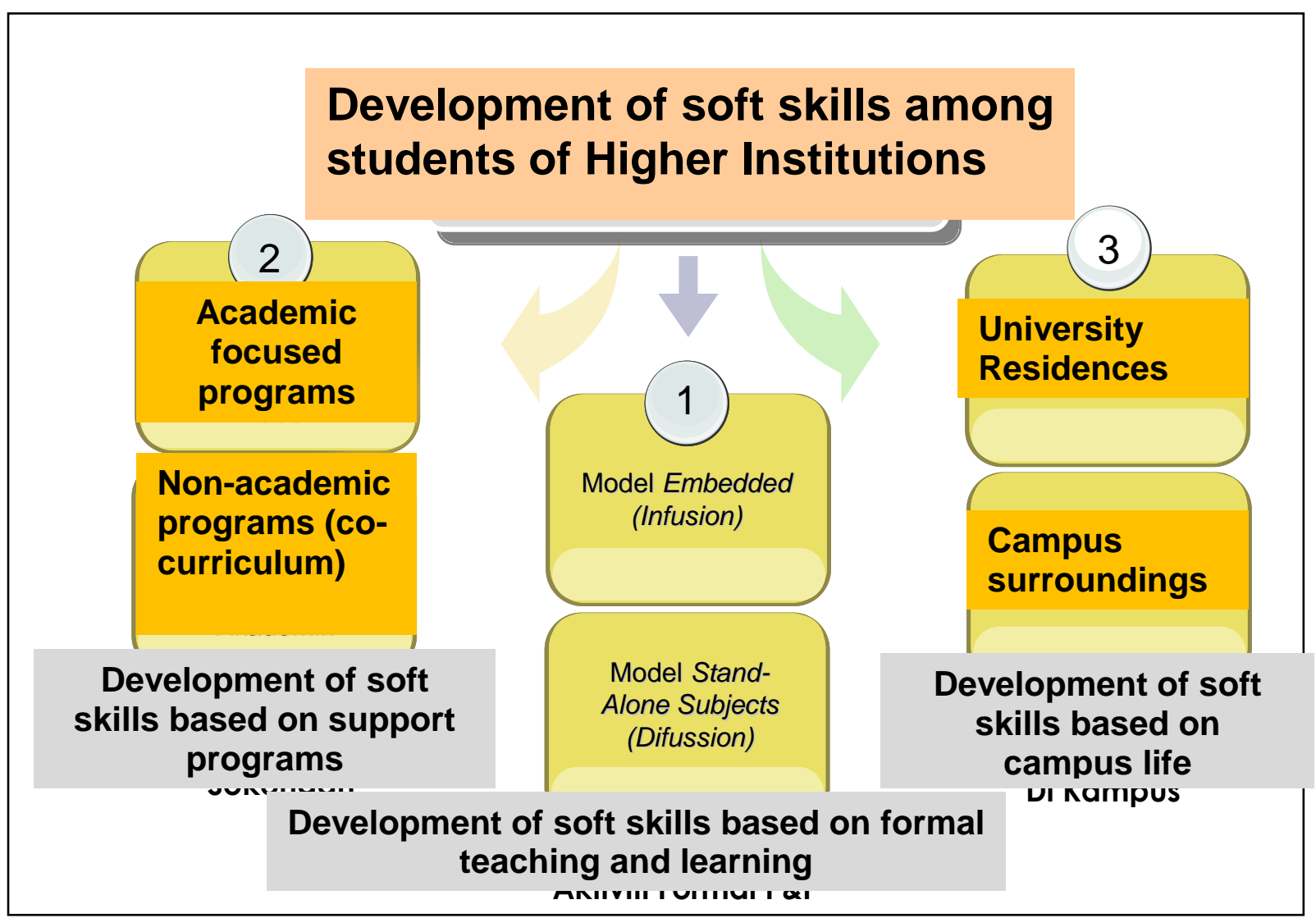

Figure 1: Development of soft skills among students of higher institutions

Pillai (2009) has highlighted that one of the ways to bridge the gap between the classroom and the workplace is to engage with industry (Teichler, 1998). In Malaysia, there has been a push towards university-industry collaboration, and the need for such collaboration is reiterated in Malaysia's National Higher Education Action Plan 2007-2010 (Ministry of Higher Education [MOHE], 2007), and the setting up of one-stop industry linkage centres on campus. At the University of Malaya (UM), industry's input and collaboration is ever present in teaching and learning (e.g. on curriculum advisory boards, as guest or visiting lecturers), research and innovation (e.g. joint research projects, consultancy, commercialisation of research output), and the training of staff and students.

For the development of the soft skills based on formal teaching and learning, it was suggested that the soft skills are best embedded in the curriculum within the objectives, learning outcomes and teaching strategies of the programmes. This can be shown in the Figure 2: 
In the implementation of the embedded model, the curriculum is based on the learning outcomes, various delivery methods and assessment methods. As in the case of the modules in Malaysia, the learning outcomes that have been developed include the seven (7) soft skills that have been identified in addition to the technical skills which were initially identified. These skills are shown in Figure 3.

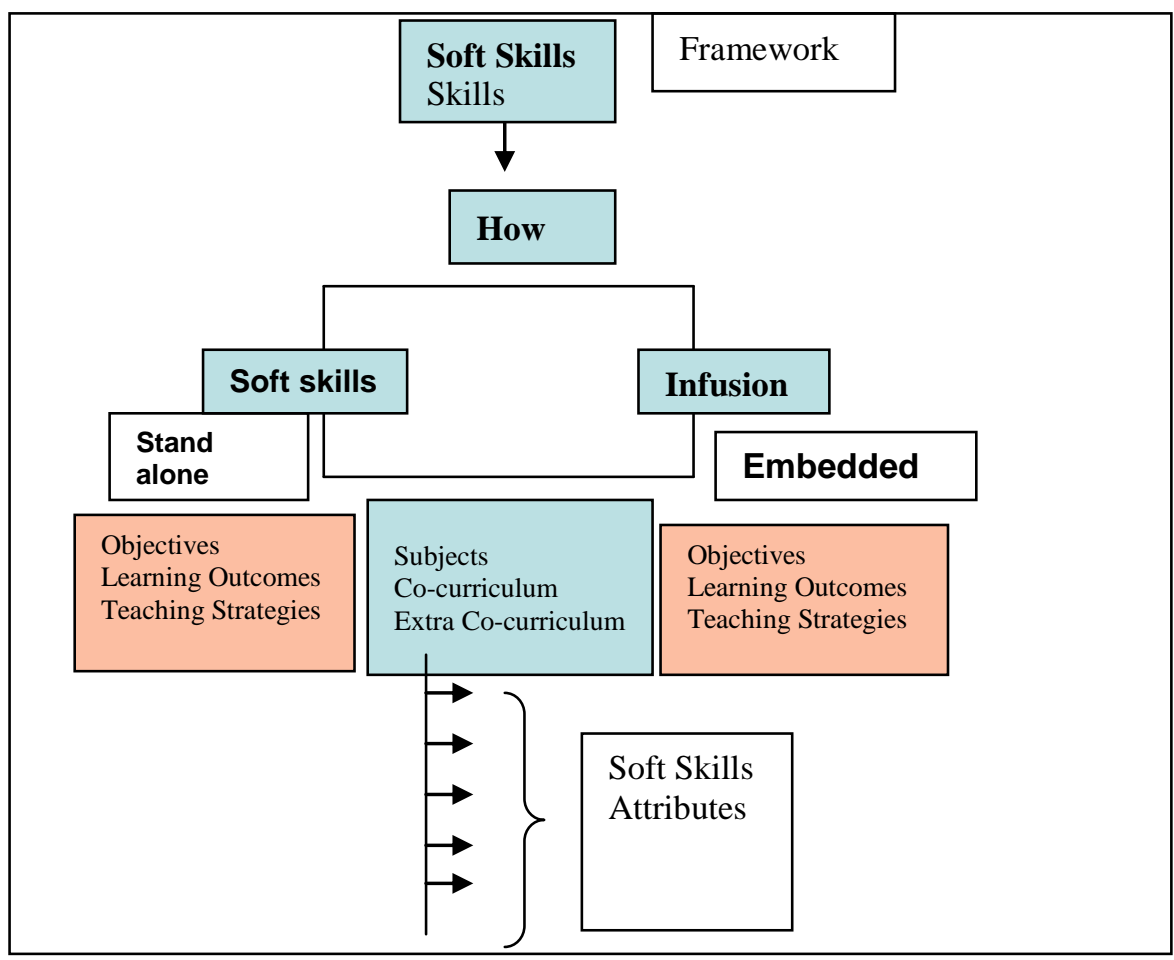

Figure 2: Framework for the Embedded or Stand alone Models

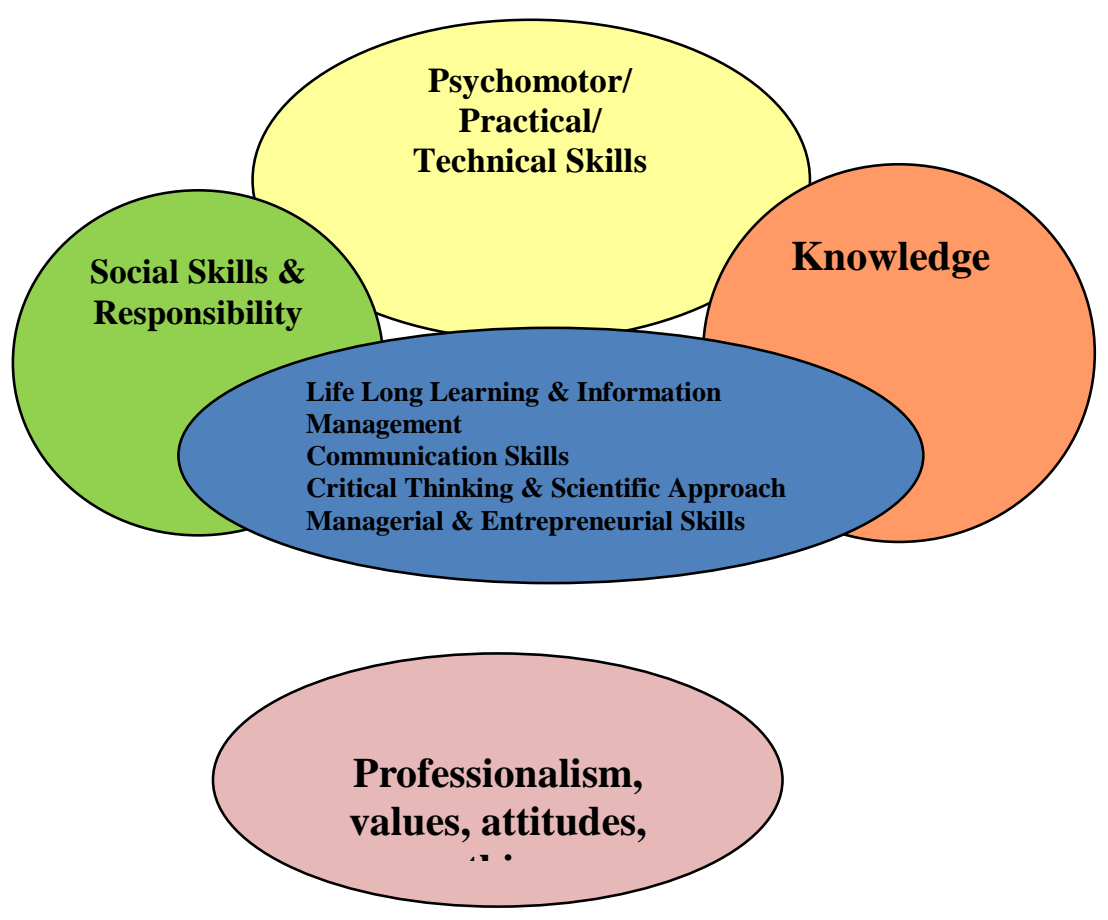

Figure 3: The identified soft skills and other skills 
Through the various delivery methods shown in Figure 4, the evaluation and rating framework for the identified soft skills are shown in Table 1. To show the multi assessment methods that have been used to rate the achievement of the soft skills, Table 2 provides an example of how the assessment for a particular course could be adopted.

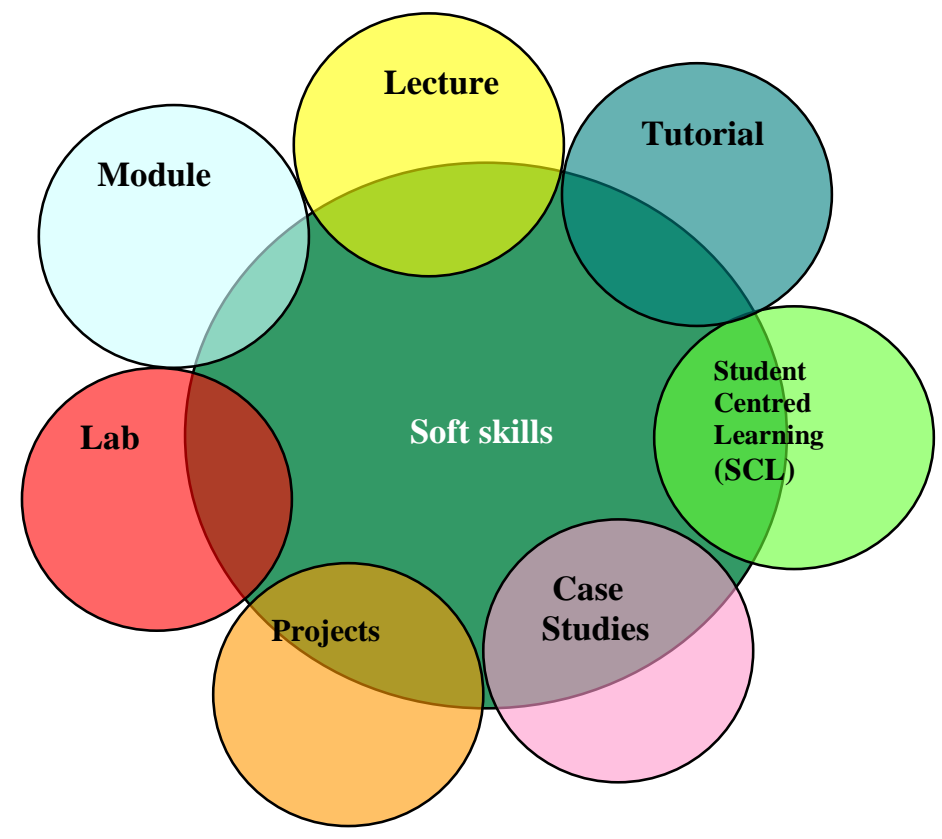

Figure 4: The various delivery methods to assess the soft skills

Table 1: Evaluation and Rating Framework for Soft Skills

\section{Evaluationand Rating Framework for Soft Skills}

\begin{tabular}{|c|c|c|c|c|c|c|c|c|}
\hline & & SCL & $\begin{array}{l}\text { Case } \\
\text { Studies }\end{array}$ & Module & Project & Lecture & Tutorial & Lab \\
\hline \multirow[t]{3}{*}{ Communication Slills } & $\operatorname{cs} 1$ & 8 & 8 & & & & 8 & \\
\hline & $\operatorname{cs} 2$ & $\therefore$ & & $=$ & & 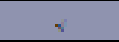 & $\therefore$ & $\therefore$ \\
\hline & $\operatorname{css} 3$ & $\therefore$ & 2 & & $\therefore$ & & $\checkmark$ & $\therefore$ \\
\hline \multirow{2}{*}{$\begin{array}{l}\text { Critical Thinking and } \\
\text { Problem Solving }\end{array}$} & CTPS1 & 8 & $\checkmark$ & & 8 & & 8 & 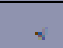 \\
\hline & CTPS2 & $\checkmark$ & $\checkmark$ & $s$ & $\checkmark$ & & $\checkmark$ & $\checkmark$ \\
\hline \multirow[t]{3}{*}{ Teamwork } & TS1 & $\checkmark$ & $\checkmark$ & & $\checkmark$ & & $\checkmark$ & $\checkmark$ \\
\hline & TS2 & $\therefore$ & $=$ & & 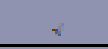 & & $\therefore$ & 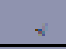 \\
\hline & TS3 & $\therefore$ & $=$ & & $\therefore$ & & $=$ & 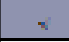 \\
\hline \multirow{2}{*}{$\begin{array}{l}\text { Information Management } \\
\text { and Lifelong L earning }\end{array}$} & LL1 & 8 & $=$ & $\checkmark$ & $\therefore$ & $\therefore$ & & \\
\hline & LL2 & 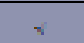 & 2 & 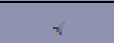 & 2 & $\checkmark$ & & \\
\hline Entrepreneurship & ES1 & & $\checkmark$ & & $\checkmark$ & & & \\
\hline \multirow[t]{2}{*}{ Ethics and Professionalism } & ET1 & $\checkmark$ & $\therefore$ & & $\therefore$ & & $\therefore$ & \\
\hline & ET2 & 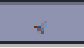 & $=$ & & 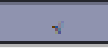 & & $\therefore$ & \\
\hline \multirow[t]{2}{*}{ Leadership } & LS1 & & & & & 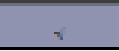 & 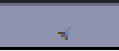 & \\
\hline & LS2 & $\checkmark$ & $\checkmark$ & & $\checkmark$ & & & $\checkmark$ \\
\hline
\end{tabular}


Table 2:

\begin{tabular}{|c|c|c|c|c|c|c|c|}
\hline Assessment Technique LO $l$ & $\begin{array}{l}\text { Writisn } \\
\text { Examination }\end{array}$ & $\begin{array}{l}\text { Oral } \\
\text { Examination }\end{array}$ & $\begin{array}{l}\text { Essopyr } \\
\text { opport }\end{array}$ & Projoo & Presentation & $\begin{array}{l}\text { Portiollo } \\
\text { 'Wobcollo }\end{array}$ & $\begin{array}{l}\text { Disoriati } \\
\text { on }\end{array}$ \\
\hline Knowledge & 4 & 4 & 4 & 4 & 3 & 4 & 4 \\
\hline $\begin{array}{l}\text { Professionalism, values, } \\
\text { attitudes and ethical } \\
\text { behaviour }\end{array}$ & 2 & 4 & 1 & 2 & 3 & 4 & 3 \\
\hline Technical Skills & 2 & 3 & 3 & 4 & 4 & 4 & 4 \\
\hline Ability to think critically & 3 & 4 & 4 & 4 & 4 & 4 & 5 \\
\hline $\begin{array}{l}\text { Management and } \\
\text { entrepreneurship skills }\end{array}$ & 1 & 2 & 3 & 4 & 4 & 4 & 4 \\
\hline $\begin{array}{l}\text { Information management and } \\
\text { lifelong learning }\end{array}$ & 1 & 2 & 3 & 4 & 4 & 4 & 4 \\
\hline Social Accountability & 1 & 2 & 2 & 3 & 3 & 3 & 3 \\
\hline $\begin{array}{l}\text { Communicate and work in } \\
\text { teams effectively }\end{array}$ & 1 & 1 & 1 & 3 & 3 & 2 & 2 \\
\hline \multicolumn{8}{|c|}{ Level of Achievement: } \\
\hline 1 & 2 & 3 & 4 & & 5 & & \\
\hline Very Lon & LoN & Moderate & Hlon & & ry Hloh & & \\
\hline
\end{tabular}

\subsection{Employers' Perception of the Soft Skills Importance for Real Estate Graduates}

In developing the various delivery and assessment methods for the real estate programme at higher learning institutions in Malaysia, it would be useful to acknowledge the employers' perception of the importance of the seven (7) soft skills which were identified earlier by the Ministry of Higher Education (MOHE).

The views of fifty (50) employers (from organisations that are listed for placement of final year student internship programme) were sought through a structured questionnaire; some were completed during an employee-student employment interview session held at the University of Malaya in November 2011 (eleven (11) organisations attended the session) and the rest were sent out to prospective employers. Fifteen (15) employers responded but only twelve (12) respondents completed the questionnaire satisfactorily. The respondent comprise $58 \%$ of local organisations and $42 \%$ of the organisations have been established over twenty (20) years. The profiles of the organisations are shown in Figures 5 and 6.

Analytic Hierarchy Process (AHP) was used to examine the relative importance of the soft skills for real estate graduates. This method is used as it makes use of a decision maker's intuitive judgements, knowledge and experience. It is also more accessible and more conducive for consensus building among decision makers in deriving the relative importance of attributes. It employs a pair-wise comparison process by comparing two objects at a time to formulate a judgement as to their relative weights. A full treatment of the methodology is discussed in Forman \& Gass (2001) and Saaty (1990) In principle, the procedure is based on comparing the importance placed on pairs of aspects one at a time. The pair-wise comparison is made in terms of preference/importance ratios evaluated on a numerical scale proposed within the method. The overall values of 
the importance are calculated by taking all possible paired combinations of the aspects comparisons. This produces the weight (in percentage form) for each individual aspect which reveals the quantum of preference attached to it. The pair-wise comparisons are then manipulated through eigen-vector calculations to create a ratio value scale that is normalised to sum to 100 percent. Based on the weights scores, the aspects can be ordered to show the order of relative importance.

Working on the data received from the fifty respondents, the results showed that ethics \& professionalism has ranked the highest in importance with a score of $19 \%$ while critical thinking \& problem solving came a rather close second with $17 \%$. The ranking then proceeded through to three other aspects (teamwork, leadership and communications) which scored $14 \%$ - $15 \%$ before getting to the lowest, for information management \& lifelong learning and entrepreneurship, with the quite distant scores of $10 \%$ each.

The above findings reinforce the discovery of the earlier study by Ranjit and Wahab (2008) which included ethics \& professionalism and critical thinking \& problem solving in their list of top ten skills sought by Malaysian employers. More specifically, they reveal that real estate employers in Malaysia look highly for these two skills in graduates but focus much less on skills associated with information management and entrepreneurship. The implications of the above findings are that the curriculum of real estate programmes in this country need to be reviewed and geared more towards the promotion of those skills in students. In accordance with this, adaptations need to be made to the course delivery modes and learning activities to achieve that aim. Assessment methods also need to do the same.

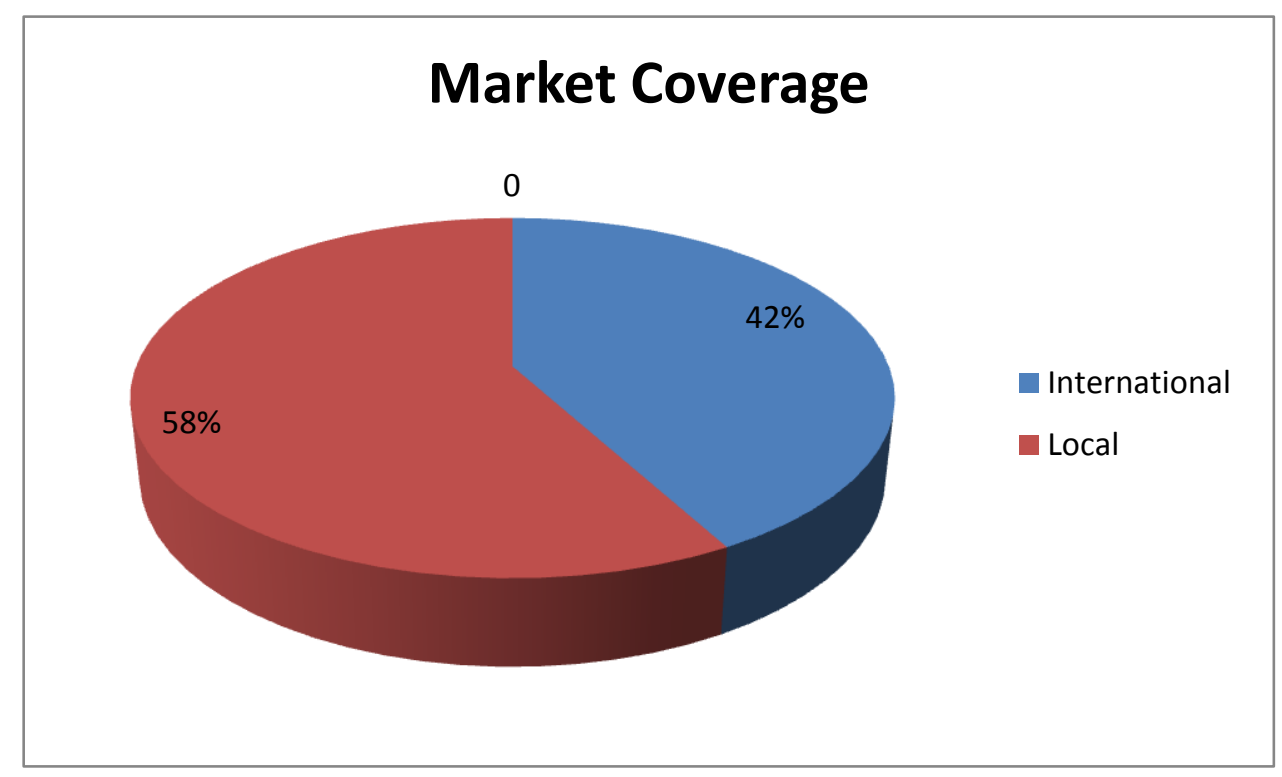

Figure 5: The market coverage of the respondent organisations 


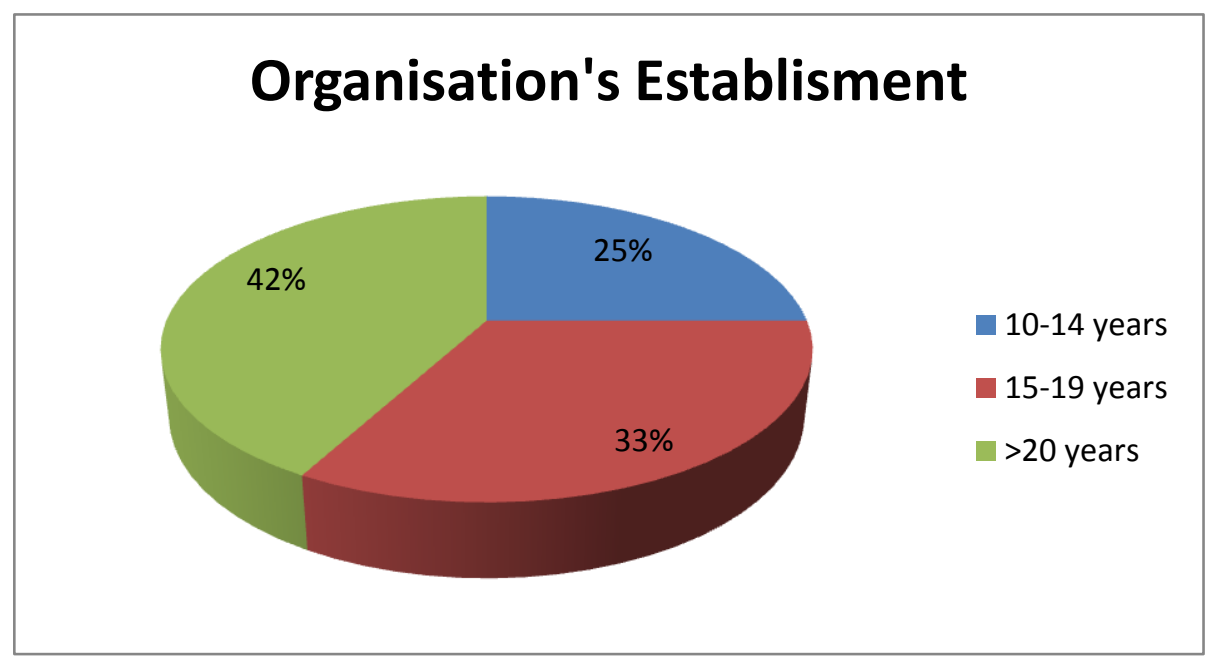

Figure 6: The number of years established

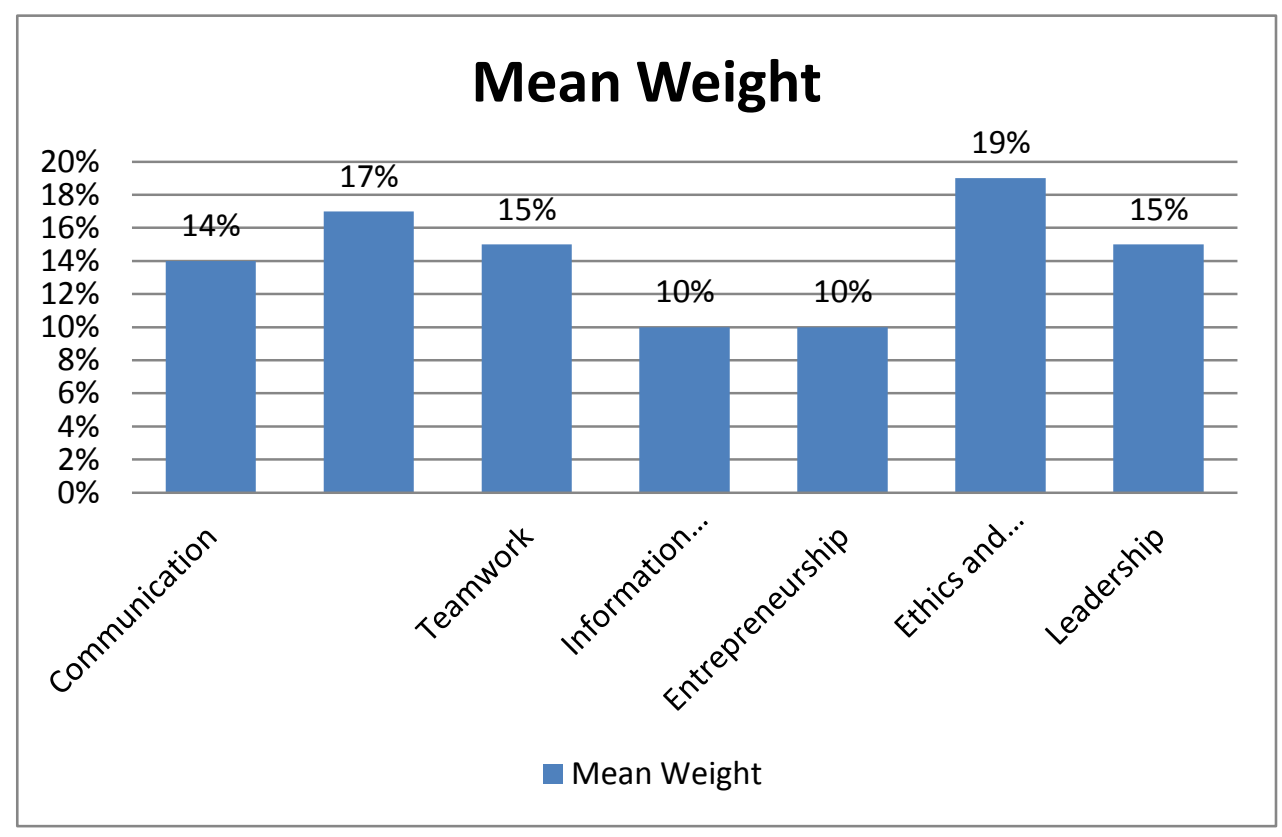

Figure 7: The mean weight of the soft skills 


\subsection{Conclusion}

In addressing the phenomenon that graduates from the local and overseas universities lack the soft skills required by the competitive job market, MOHE has taken steps to develop a module to enhance these skills. This was brought about of the feedback from employers locally and abroad which have noted that graduates lack the soft skills when seeking employment. In addressing the issue, a comprehensive module has been developed by MOHE for the implementation at the higher learning institutions to cater for the enhancement of the soft skills. From a survey among the real estate employers on the relative importance of the identified seven (7) soft skills, it can be observed that that there is no major differences of importance. Ethic and professionalism has the highest relative weight while information management \& lifelong learning and entrepreneurship are given the lowest relative weights. With the confirmation of the relative importance of the soft skills for real estate programmes, it would be useful to consider the appropriate implementation and assessment methods to ensure that the graduates are equipped with the necessary soft skills.

\subsection{References}

Accreditation Board for Engineering and Technology (ABET), 2008. Criteria for accreditation of engineering programs. [Online]. Baltimore: Engineering Accreditation Commission.Available from: http://www.abet.org/ [accessed August 2008].

Adnan, Y M and Aini, A M (2006), Sharing The Initial Experience Of Implementation Of Problem Based Learning (PBL) at The Department Of Estate Management, Faculty Of Built Environment, University Of Malaya, proceedings the Second Annual Built Environment Education Conference, BEECON 2006, London, 12-13th September 2006

Archer, W. and Davison J. (2008) Graduate employability: What do employers think and want? London, the Council for Industry and Higher Education (CIHE)

Birkett, WP (1993), Competency based standards for professional accountants in Australia and New Zealand, Melbourne, Australia: Australian Society for Certified Practicing Accountants

Brown, P., Hesketh, A., \& Williams, S. (2004). The management of talent. Oxford: Oxford University Press.

CBI, http://educationandskills.cbi.org.uk/case_studies/

Commonwealth of Australia. 2007. Graduate employability skills. [Online]. Prepared for the Business, Industry and Higher Education Collaboration Council. Available from http://www.dest.gov.au [accessed August 2008].

Cotton, K (2001), Developing employability Skills, Northwest Regional Educational Research Laboratory, Portland OR available at www.nwrel.org/scpd/sirs/8/c015.html (accessed 27 November 2007)

DEST. 2002. Employability Skills For The Future, a report by the Australian Chamber of Commerce and Industry and the Business Council of Australia for the Department of

Education, Science and Training, Canberra.

Enhancing employability, recognising diversity - making links between higher education and the world of work, Universities UK and the HECSU, 2002.

Employability of Malaysian Graduates presented to the Majlis Tindakan Ekonomi Malaysia, April 2003. 
Enhancing the Quality of Higher Education through Research - Shaping Future Policy (pp. 136-156). Putrajaya: MOHE.

Engineers Australia, 2008. [Online] Available from: http://www.engineersaustralia.org.au/ [accessed August 2008].

Glass, A. Landsburgh, H. Quashie, A and McGregor A(2008). The Work-Readiness of Recruits from Colleges and Universities in Scotland: Full Report. Training and Employment Research Unit TERU) University of Glasgow.

Hesketh, A. (2000), “Recruiting an elite? Employers' perceptions of graduate employment and training", Journal of Education and Work, Vol. 13 No. 3, pp. 245-71.

Hii, C. (2007, November 11). Need to resolve mismatch in the job market. The Star Online. Retrieved February 4, 2009, from http://thestar.com.my

Jolly, L., 2001. Implementing graduate attributes, the value added career start program. [Online]. Available at: http://www.vacs.uq.edu.au/final/1_10.pdf [accessed August 2008].

Kemper, CL (1999), EQ vs IQ, communication World, 16(9), 15-19

Mc Murchie, LL (1998), Careers can rise and fall with EQ, Computing Canada, 1(9), 18-21

Kim, Young-Hwa (2002), “A State of Art Review on the Impact of Technology on Skill Demand in OECD Countries", Journal of Education and Work, Vol. 15, No. 1, pp.89-109.

Ministry of Higher Education, Malaysia, Module for the Development of Soft Skills for Higher Learning Institution Malaysia, 2006

Moreland, N (2006), Entrepreneurship \& Higher Education: An Employability Perspective, Learning \& employability Series, ESECT, York

Nurita, Shaharudin and Ainon (2004). Perceived employability skills of graduating students:Implications for SMES.

Organisation for Economic Cooperation and Development (OECD) (2001) Competencies for the Knowledge Economy. Paris: OECD (accessible: www.oecd.org/dataoecd/42/25/1842070.pdf)

Organisation for Economic Co-operation and Development. (2011). Towards an OECD skills strategy (Meeting of the OECD Council at Ministerial Level Paris, 25-26 May 2011). Paris: Organisation for Economic Cooperation and Development.

Page, C, Wilson, M, Kolb, D (1993), Managerial competencies and New Zealand manages: On the inside, looking in. Auckland, New Zealand: University of Auckland

Pillai, S., Khan, M. H., Hassan, A. A., \& Raphael, S. (2009). The Industrial Training Experience: Industry's Perceptions of UM Students [Poster]. UM Research, Invention \& Innovation Expo 2009. University of Malaya, 13-15 January 2009

Pillai S (2009), University Industry Partnership - ASAIHL 2009, University of Kelaniya, Sri Lanka

Ranjit, S. M. (2009). Make yourself employable: How graduates can hit the ground running! Kuala Lumpur: TQM Consultants Sdn. Bhd.

Ranjit, S. M., \& Wahab, A. B. (2008). Your dream job: How to get it and excel. Kuala Lumpur: TQM Consultants Sdn. Bhd.

Report of the Industry Dialogue (2008). Industry-Education Collaboration for Sustainable Workforce Development - Meeting the Challenges. Conducted by the Department of Polytechnic and Community College Education: MOHE. 
Sirat, M., Pandian, A., Muniandy, B., Mohamed Sultan, F. M., Haroon, H. A., Kabilan, M. K., Abdul Razak, R. R. (2008). The university curriculum and the employment of graduates. In Zuraidah Mohd Don et al. (Eds.)

Subra: Graduates lack dynamism and edge. (2009, February 16). The Star Online. Retrieved 17 February, 2009, from http://thestar.com.my.

Taylor, R. (2006), Skills and Innovation in Modern Workplaces, An ESRC Future of Work Programme Seminar Series, www.esrc.ac.uk/ESRCInfoCentre/Images/fow punlication 6 tcm6-6061.pdf (Accessed: 2012, 20 October)

Teichler, U. (1998). The requirements of the world of work. In Proceedings of the World Conference on Higher Education - Higher Education in the Twenty-first Century: Vision and Action: Vol: IV. UNESCO.

The Dearing Report: "Higher Education in the Learning Society", Report of the National Committee of Inquiry into Higher Education, chaired by Lord Dearing, July 23, House of Lords Papers, 1997-1998, www.leeds.ac.uk/educo/ncihe (Accessed: 2005, July 3)

Toner, P. (2011), "Workforce Skills and Innovation: An Overview of Major Themes in the Literature", OECD Education Working Papers, No. 55

80,000 Graduan Menganggur, Mingguan Malaysia, February 20, 2005

Weber, M.R., Finely, D.A., Crawford, A. \& Rivera, D.J. 2009. An exploratory study identifying soft skill competencies in entry-level managers. Tourism and Hospitality Research, 9(4):353-361

West, A., Noden, P., \& Gosling, R. (2000). Quality in higher education: an international perspective: the views of transnational corporations. Clare Market Papers No. 17. London: Education Research Group, LSE.

Why local Grads Losing Out, News Straits Times, April 20, 2005

17,000 IT Grads from Local Varsities jobless due to poor English, News Straits Times, September, 2003

Yim-Teo T.(2004) Reforming Curriculum for a Knowledge Economy, the Case of Technical Education in Singapore. Presented at the Education that Works: The NCIIA 8th Annual Meeting, 18-20 March in Nanyang Technological University, Singapore 